mouth with the MS-1 strain of hepatitis A virus (Feinstone and colleagues, Science, 182, 1026; 1973). The particles were heavily coated with antibody and they were aggregated by convalescent serum. These particles were not found in faecal specimens before infection, they were only detected at the onset of clinical symptoms, and pre-illness sera did not contain antibodies to the viruslike particles. Faecal filtrates containing these $27 \mathrm{~nm}$ virus-like structures were used to examine by electron microscopy several groups of sera for the presence of antibody. All 6 volunteers previously infected with hepatitis A developed serological evidence of infection as judged by aggregation and antibody coating of the $27 \mathrm{~nm}$ particles. Similar results were obtained with sera from patients with a number of naturally occurring outbreaks of hepatitis A. Other studies have shown that the buoyant density of the faecal particles in caesium chloride was 1.41 $\mathrm{g} \mathrm{ml}^{-1}$ and together with the morphological appearance and known resistance to ether, acid and heat the data suggest that this particle is a parvovirus (Feinstone and associates, $J$. Virol., 13, 1412; 1974). Morphologically and antigenically similar particles were also demonstrated in faeces from patients from at least one geographically separated outbreak of hepatitis A (J. Maynard and colleagues, personal communication). The particles identified in Arizona banded, however, in two peaks in caesium chloride at 1.291.33 and at $1.39 \mathrm{~g} \mathrm{ml}^{-1}$. Preliminary data from experimental transmission to marmosets and susceptible chimpanzees have also demonstrated a close association between the faecal particles and hepatitis A.

On the other hand, it is generally recognised that faeces contain a multitude of bacterial, bacteriophage, viral and other particulate antigens. Almeida and her colleagues (Lancet, ii, 748; 1974) examined by immune electron microscopy and by immunodiffusion faecal extracts and acute and convalescent sera from an outbreak of hepatitis A. Faecal extracts reacted with convalescent sera contained frequent distinctive aggregates having the appearance associated with immune complexes. But particles resembling bacteriophage, particles resembling togavirus and a range of spherical particles were all present in distinct immune complex form. Serological analysis by gel diffusion showed seroconversion to more than one antigen present in the faeces, and seroconversion was also detected to antigens present in a number of control faecal extracts. It was also pointed out that it is known that antibody titres to bacterial, viral and dietary antigens are increased in patients with acute and chronic liver disease and this may account for the multiplicity of immune reactions in viral hepatitis.

The latest results reported by Almeida and colleagues (Lancet, ii, 1083; 1974) after the examination of faecal extracts from one of the infected adult volunteers tested by Feinstone and associates (loc. cit.) confirmed the presence of the $27 \mathrm{~nm}$ particles, but at least two small cubic virus-like particles were found in addition. Using the technique of immune electron microscopy in London, extracts of faeces obtained 33 days after infection with the MS-1 strain of hepatitis A were found to contain virus-like structures which varied in their size. Both 'full' and 'empty' particles measuring $22 \mathrm{~nm}$, $27 \mathrm{~nm}$ and $30 \mathrm{~nm}$ in diameter could be distinguished and they seemed to have a cubic symmetry. Each of these viruslike structures was clearly coated with antibody and the particles were aggregated by convalescent but not by acute serum from hepatitis type $A$. The fact that this material has also induced hepatitis in 2 out of 6 marmosets suggests that hepatitis $\mathrm{A}$ virus is indeed present. But the precise relationship to the disease of the three virus-like particles now described remains uncertain.

The success of immune electron microscopy in elucidating the complex antigenic reactivities of hepatitis $\mathbf{B}$ virus may blaze a trail for what seems to be an equally puzzling array of particles present in the faeces, and perhaps the serum, of patients with hepatitis A infection.

\section{Eclogite model of upper mantle}

from Peter J. Smith

THE view that the Earth's upper mantle might be eclogitic in composition was put forward over 60 years ago by Fermor (Rec. Geol. Surv. India, 43, 41; 1913), although since then it has received comparatively little support. According to Green and Ringwood (Phys. Earth Planet, Interiors, 3, 359; 1970), for example, "the weight of geological and geophysical evidence on upper mantle composition favours an overall peridotitic composition", and the arguments against an eclogitic composition were given by Ringwood and Green (Tectonophysics, 3, 383; 1966). During the past decade, Green and Ringwood (see, for example, Earth planet. Sci. Lett., 3, 151; 1967) have given particular attention instead to their "pyrolite" composition, although the validity of this system is by no means universally accepted.

Interest in the eclogite model began to revive in 1970 when Press (Phys. Earth Planet. Interiors, 3, 3; 1970) used a Monte Carlo procedure to derive a series of Eanth models consistent with geophysical data. Specifically, he found that of about 50 acceptable density models, about 30 required densities of at least $3.6 \mathrm{~g} \mathrm{~cm}^{-1}$ somewhere in the upper mantle. Both Press and Birch (Phys. Earth Planet. Interiors, 3, 178; 1970) interpreted these high densities to favour almost exclusively an eclogitic composition for the upper mantle, and thus for the low velocity zone, although Birch did add that an iron-rich olivine upper mantle might still be possible. At this point, however, it became clear that any detailed discussion of an eclogitic upper mantle would be seriously hampered by the relative lack of experimental data on eclogites, in particular on their elastic properties.

Some results on the seismic velocities in eclogites have now been provided by Rao et al. (Earth planet. Sci. Lett., 23, 15; 1974), and they show just how involved the situation is. Eclogites from India, Czechoslovakia and Japan all have comparable garnet compositions and mean atomic weights, but there are significant differences in $P$ wave velocities and velocity-pressure gradients. Velocities at $4 \mathrm{kbar}$, for example, range from $7.43 \mathrm{~km} \mathrm{~s}^{-1}$ for the Indian eclogites, through $8.05 \mathrm{~km} \mathrm{~s}^{-1}$ for those from Japan, to $8.35 \mathrm{~km} \mathrm{~s}^{-1}$ for the Czechoslovakian samples. For the same location order, average velocitypressure gradients are, respectively, $0.08,0.058$ and $0.036 \mathrm{~km} \mathrm{~s}^{-1} \mathrm{kbar}^{-1}$.

The reason for these variations is that the apparent distribution constant $(K)$ of $\mathrm{Fe}-\mathrm{Mg}$ between coexisting garnets and pyroxenes varies from one set of eclogites to the other, indicating that the conditions of temperature and pressure under which they formed were different. In fact, Rao and his colleagues are able to demonstrate a linear relationship between $\mathbf{P}$ wave velocity and $K$. But details apart, the general point to be made is that if the eclogite model is now to be considered seriously, much more experimental work will be required to elucidate the complexities of eclogite systems-as much, perhaps, as has been done on the more popular pyrolite systems.

\section{Erratum}

In the article "The Linear Differentiation of Chromosomes" (Nature, 252, $95 ; 1974)$ the statement was made that "the many current attempts to explain banding reflect our lack of knowledge of how $1 \mathrm{~cm}$ of DNA can be packed with protein into a $1 \mathrm{~mm}$ transverse band". $1 \mathrm{~cm}$ of DNA is in fact packed into a $1 \mu \mathrm{m}$ transverse band. 